
opportunity to build up the supply of power
which would enable development to take place.

The total world consumption of power in the year 1950 was some 30,000 million kilowatt-hours. On a United Nations estimate of the annual rate of increase of power consumption at $3 t$ per cent the year A.D. 2000 would see a three-fold increase on the present demand for power. This must be met very largely from nuclear energy, for by that time coal and oil outputs would be well past their peaks and hydroelectric power would be approaching its full development. It should be noted that the present methods of generating electric power, by means of a thermal cycle, were inherently wasteful, nearly four-fifths of the available heat being rejected. If this rate of loss should continue the world would in fifty years' time be wasting heat in the production of electricity at a level in excess of twice the present total world consumption of power.

Referring to engineering as a career and to the present shortage of engineering graduates, Prof. Say drew a comparison between the situation in the
U.S.S.R. and in Britain. It was worth noting that despite the scale of the Russian need for engineers and scientists there was no extreme specialization in science in the secondary schools. In the U.S.S.R. the three final years of school, to age seventeen, included the study of physics, chemistry and mathematics for about 40 per cent of the time, and this held for all pupils, arts as well as science. Thus potential arts men had to pass examinations in science subjects while potential engineers and scientists had to study literary subjects to a level quite beyond that of the average British technical student.

The concluding section of Prof. Say's address was concerned with the ultimate values in human life and the possible threat which was offered by the pressure and strain of a mechanistic age to the qualities of imagination and creation which were key elements in the human make-up. "We cannot deny," he said, "that the threat exists, nor on the other hand that industrialization has brought great benefits to mankind. It will bring more, but only if the mastery remains where it belongs-in the care of the human spirit."
J. GREIG

\title{
NATURAL HISTORY OF THE FOX SQUIRREL
}

\begin{abstract}
A
FIELD study of the fox squirrel (Sciurus niger) in the south-eastern coastal area of the United States has been made by J. C. Moore (Bull. Amer. Mus. Nat. Hist., 13, Art. 1). The fox squirrel has probably diminished greatly in numbers and range because of changes wrought by man. Sciurus niger shermani was investigated in the sand hills of north Florida in a fir-maintained plant community which is common over a wide area of the south-eastern coastal plain, the Pinus australis-Quercus laevis associates. This plant community was changed suddenly and radically from a tall but very open forest of primeval long-leaf pines with turkey oak indifferently represented as a secondary, lower level dominant, to a virtually pure stand of turkey oak, relatively close-ranked and low.

Moore's inquiry was designed to determine how this large tree squirrel, after presumably evolving in the open stands of large pines, lives now in the lowly oak forest which has succeeded the logged-off pine.

The principal predatory enemies of Stiurus niger shermani are apparently the bold eagle, the red-
\end{abstract}

tailed hawk, and man. There are few suitable refuges for so large a tree squirrel in this low, open forest of deciduous trees and this may have brought about the following developments in behaviour unusual for a tree squirrel : a fairly well-established tendency for it to take refuge, when hard pressed, in the burrows of gopher tortoises underground; the use by the fox squirrels of hollows that extend down through the tops of old stumps to nesting chambers underground ; an escape behaviour, which may have developed since the removal of the old pines and which is presumed to be employed only against man, that involves hiding in the top of a second-growth long-leaf pine by ascending the plume-like apical twig so that the twig bends over horizontally under the squirrel, and the squirrel lies on top hidden from all below ; there is, apparently, an excessive number of leaf-nests per individual squirrel, thus providing more refuge.

While these forms of behaviour have survival value, they do not enable the animal to prosper.

\section{THE BRITISH COUNCIL}

HE annual report of the British Council for
$1956-57$ refers briefly to the review of Overseas
Information Services made by Dr. C. Hill. The
decisions recorded in the White Paper accepted about
nine-tenths of the Council's proposals for increased
activities and the Council specially welcome the
reference to co-operation with people and interests
outside the Government. The Council's work depends
largely on the help and advice of many educational,
professional, scientific and industrial bodies as well as
of thousands of individuals. About half the report
deals with the Council and the sciences and an
increasing proportion of the Council's work consists
of making known British scientific achievement,
assisting the dissemination of information to the
appropriate specialists and in serving as a link
between British experts and professional bodies and their opposite numbers abroad. Allied to this is assistance in training. Since 1950, the number of overseas students in the United Kingdom has risen from 10,000 to nearly 35,000 , about a third of whom are at universities or university colleges, while 60 per cent are concerned with the sciences. By far the largest increase in students is among those attending technical colleges, and the numbers might be greater still if their countries could find the necessary funds or Britain could offer scholarships and places on the scale of some of her competitors.

The report stresses Britain's advantage, shared with the Commonwealth and the United States, in the establishment of the English language among scientists as an essential means of communication, and the Council's work in furthering the study of English is thus of importance in this connexion. The 
University of Edinburgh inaugurated its now School of Applied Linguistics in October 1957. This is conceived especially for those who are responsible for training teachers of English and the establishment or revision of teacher-training methods. Three Council officers are participating in the course together with experts in teaching English from oversees invited by the Council. English language teaching now occupies so important a place in the Council's activities that the English Studies Advisory Committee has been divided into two separate panels, one advising on literature and the other on language.

In fostering the knowledge of British scientific achievements, the Council's special function is to use its staff in the field to find out what demands for information and training are being left unsatisfied and to put learned institutions and individual scientists overseas in touch with the appropriate organization or individuels here. Even within the Commonweslth the established links are not always adequate and the Council has been able to reinforce them by, for example, the exchange of delegates between the British Association and the corresponding organizations in Ceylon, India and Pakistan, by showing medical films in the more advanced Colonies, sending lecturers on such subjects as the use and local manufacture of laboratory apparatus, or enlisting the help of specialists who happen to be visiting the territories.

The Council's most important role in the sciences is in promoting visits by scientists to and from Britain for discussion, observation and study, and of all the visitors to Britain for which the Council makes arrangements about 13 per cent are financed by the Council. In the past five years the Council has assisted in some 7,000 visits of individuals in the sciences, or about 32 per cent of the total for all subjects. Of the Council's postgraduate scholarships, 594 or 56 per cent of the total in the past five years went to the sciences, and for the 221 awards in 195657 there were 2,500 applicants. The Council is also the national supervising agency for the United Nations Technical Assistance Administration Fellow. ship Scheme and other Fellowship Schemes of the Specialized Agencies under which 2,941 Fellows have visited the United Kingdom during the past ten years, of whom about two-thirds were concerned with science and technology, medicine, agriculture and training leading to development. Among the shortterm visitors, the proportion whose interests lie in science has increased since 1950 from 25 to 30 per cent, but among the bursars it has increased from 25 to 40 per cent. There have been few changes in emphasis as regards subject, though interest in the nuclear sciences has grown and the organization of technical education has greatly increased, while the steadily growing demand for British professors, lecturers and teachers is reflected in the number of rectors of overseas universities, senior officiels of Ministries of Education, and principals of teacher-training colleges who have sought the Council's help, first to study the organization of research in Britain and our methods of teaching scientific and technical staff, and then in recruiting British staff for their own institutions.

The Council operates two schemes for the interchange of university teachers, one dealing with Western European countries and the other with the Commonwealth, under which 161 scientists from United Kingdom universities have visited thirteen European countries and 62 have visited Commonwealth countries. There have been 154 reciprocal visits from foreign countries and 200 from the Commonwerlth, the percentage of all these visits devoted to the soience being 60 . Under the interchange scheme for younger research workers started in 1954 there have been 33 visits from the United Kingdom to four European countries and 27 visits from these countries to the United Kingdom. Stress is also laid on the lecture and advisory tours of specialists which the Council organizes in co-operation with overseas countries, and in 1956-57 the Council initiated a pilot project to enable British experts to visit and work in Latin American universities and research institutions under which four such visits were arranged between July 1956 and March 1957. During the pest five years the Council has aceepted responsibility for recruitment to some forty vacancies for British scientists in teaching posts in universities and schools, but not all these have been filled.

More than 6,000 British papers from learned periodicals were supplied in 1956-57 and more than 400 specialists from some 70 countries visited the Council's medical and science libraries. Noteworthy among the group exchange visits with the U.S.S.R., arranged by the Soviet Relations Committee of the Council, were the exchanges of delegations between the Royel Society and the U.S.S.R. Acaderny of Sciences; between the Royal College of Surgeons of England and the Royal College of Surgeons, Edinburgh, and Russian surgeons; and exchanges of delegations interested in engineering education and training, whose programme in Britain was organized by the major engineering institutions. These visits, as Sir David Kelly emphasizes, were in marked contrast to others, non-reciprocal, since the Soviet delegations were interested simply in acquiring technical information.

\section{DIAMONDS IN SIBERIA}

\section{BY PROF. S. I. TOMKEIEFF}

NTIL quite recently no diamond deposits in the
territory of the U.S.S.R. were known, while at
the same time the rapid progress of industrialization
was pressing for a supply of industrial diamonds,
which had to be imported from abroad. This
prompted the Soviet Government, through the appro-
priate channels of the Geological Survey, the Ministry
of Geology and the Academy of Sciences, to embark
on a series of planned explorations for diamonds. In
1941, diamond placers were discovered in the Urals, but these proved to be of no commercial value. In 1944 the wild tracts of taiga, situated between the rivers of Enisey and Lena, were selected as a possible diamantiferous region, and this selection proved to be a correct one, for in 1948 diamond placers were discovered in the basin of Nizhneya Tunguska, in 1949 in the basin of Vilui, and finally in 1954 the first kimberlite pipe, named 'Zarnitza', was discovered in the basin of Daldyn, in the north-west Yakutia. Subsequent explorations and prospecting greatly 